\title{
FAKTOR-FAKTOR YANG MEMPENGARUHI TERJADINYA STUNTING PADA BALITA USIA 24-59 BULAN
}

\author{
Lisa Tanzil', Hafriani² \\ 1,2STIKes Getsempena Lhoksukon, \\ 1email: lisatanzil02@gmail.com \\ ²email: hafriani.sst@gmail.com
}

\section{ABSTRACT FACTORS AFFECTING STUNTING IN CHILDREN AGE 24-59 MONTHS}

Background: Stunting is a description of chronic malnutrition in the period of growth and development since early life. Many factors can cause stunting in children under five, such as the characteristics of toddlers and socioeconomic characteristics. The prevalence of stunting in Indonesia is the fifth largest in the world. Basic health research data (Riskesdas) in 2013 showed the prevalence of stunting in the national scope of 37.2 percent, consisting of a stunting prevalence of 18.0 percent and very short prevalence of 19.2 percent. Stunting is considered a serious public health problem when the prevalence of stunting is in the 30-39 percent range.

Purpose: This study aims to determine the factors that cause stunting in toddlers aged 24-59 months

Methods: This study was an analytic observational study with a case control conducted in the working area of the Simpang Ulim Public Health Center, East Aceh. Samples were taken as many as 20 toddlers as a case group and 20 toddlers as a control group with a purposive sampling technique. Data analysis used the chi square test and used cross tabulation to analyze the closeness of the relationship between two variables by looking at the Odds Ratio (OR) value.

Results: The study showed that energy adequacy (OR =9,333; $\mathrm{Cl}=2,180-39,962)$, protein adequacy (OR $=7000 ; \mathrm{Cl}=1,739-28,174)$, maternal $\mathrm{knowledge}(\mathrm{OR}=7000 ; \mathrm{Cl}=1.739-28174)$, maternal education $(\mathrm{OR}=22,667$; $\mathrm{Cl}=4,374-117,468)$, family income $(O R=13,222 ; C l=2,790-62,670)$ was a risk factor for stunting, while other factors in this study were low birth weight $(L B W)(O R=1,588 ; \mathrm{Cl}(0.236-10.704)$, history of breastfeeding $(O R=$ 0.474; $\mathrm{Cl}(0.39-5.688)$ and maternal occupation $(O R=1.238 ; \mathrm{Cl}=0.343-4.64)$ were not risk factors for stunting.

Conclusion: Lack of energy and protein intake, less knowledge of mothers, low education of mothers and low family income are risk factors for stunting in children aged 24-59 months.

Suggestion It is hoped that the Puskesmas and other related sectors can increase maternal knowledge about the nutritional needs of toddlers through nutritional counseling activities which include education on nutritional adequacy rates for children under five according to age, how to properly process food, and provide financial assistance for underprivileged families. It is hoped that mothers of toddlers can actively participate in posyandu activities so that they are more often exposed to nutritional fulfillment information for toddlers.

Keywords: Stunting, Risk Factor, Toddler, Simpang Ulim

\footnotetext{
ABSTRAK

Latar Belakang: Stunting merupakan penggambaran dari status gizi kurang yang bersifat kronik pada masa pertumbuhan dan perkembangan sejak awal kehidupan. Banyak factor yang dapat menyebabkan terjadinya stunting pada balita seperti karakteristik balita maupun social ekonomi. Prevalensi stunting di Indonesia menempati peringkat kelima terbesar di dunia. Data Riset kesehatan dasar (Riskesdas) tahun 2013 menunjukkan prevalensi stunting dalam lingkup nasional sebesar 37,2 persen, terdiri dari prevalensi pendek sebesar 18,0 persen dan sangat pendek sebesar 19,2 persen. Stunting dianggap sebagai masalah kesehatan masyarakat yang berat bila prevalensi stunting berada pada rentang 30-39 persen.

Tujuan: Penelitian ini bertujuan untuk mengetahui factor-faktor yang menyebabkan terjadinya stunting pada balita usia $24-59$ bulan.

Metode: Penelitian ini merupakan penelitian observasional analitik dengan kasus kontrol yang dilakukan di wilayah kerja UPTD Puskesmas Simpang Ulim, Aceh Timur. Sampel yang diambil sebanyak 20 balita sebagai kelompok kasus dan 20 balita sebagai kelompok kontrol dengan teknik purposive sampling. Analisis data menggunakan uji chi square serta menggunakan tabulasi silang untuk menganalisis keeratan hubungan antara dua variabel dengan melihat nilai Odds Ratio (OR).
} 
Hasil: Pada penelitian menunjukkan bahwa kecukupan energy (OR=9.333; $\mathrm{Cl}=2.180-39.962)$, kecukupan protein (OR=7000; $\mathrm{Cl}=1.739-28.174)$, pengetahuan ibu (OR=7000; $\mathrm{Cl}=1.739-28174)$, pendidikan ibu (OR=22.667; $\mathrm{Cl}=4.374-117.468)$, pendapatan keluarga $(\mathrm{OR}=13.222 ; \mathrm{Cl}=2.790-62.670)$ merupakan factor resiko terjadinya stunting, sedangkan factor lainnya dalam penelitian ini yaitu berat badan lahir rendah $(B B L R)(O R=1.588 ; \mathrm{Cl}$ (0.236-10.704), Riwayat $\mathrm{ASI}(\mathrm{OR}=0.474 ; \mathrm{Cl}(0.39-5.688)$ dan pekerjaan ibu (OR=1.238; $\mathrm{Cl}=0.343-4.64)$ bukan merupakan factor resiko terjadinya stunting.

Kesimpulan: Asupan energi dan protein yang kurang, pengetahuan ibu yang kurang, pendidikan ibu yang rendah serta pendapatan keluarga yang rendah merupakan fakor resiko terjadinya stunting pada balita usia 24-59 bulan.

Saran Bagi pihak Puskesmas dan lintas sektoral yang terkait diharapkan dapat meningkatkan pengetahuan ibu tentang kebutuhan nutrisi pada balita melalui kegiatan penyuluhan gizi yang meliputi edukasi mengenai angka kecukupan gizi pada balita sesuai umur, cara mengolah makanan yang benar, serta memberikan bantuan finansial bagi keluarga yang tidak mampu. Bagi ibu balita diharapkan dapat aktif mengikuti kegiatan posyandu supaya lebih sering terpapar dengan informasi pemenuhan nutrisi pada balita.

Kata kunci : Stunting, Factor Resiko, Balita, Simpang Ulim

\section{PENDAHULUAN}

Stunting atau balita pendek adalah balita dengan masalah gizi kronik, yang memiliki status gizi berdasarkan panjang atau tinggi badan menurut umur balita jika dibandingkan dengan standar baku WHO-MGRS (Multicentre Growth Reference Study) tahun 2005, memiliki nilai z-score kurang dari -2SD dan apabila nilai z-scorenya kurang dari-3SD dikategorikan sebagai balita sangat pendek (Pusdatin, 2015).

Factor penyebab stunting terdiri dari factor basic seperti factor ekonomi dan pendidikan ibu, kemudian factor intermediet seperti jumlah anggotakeluarga, tinggi badan ibu, usia ibu, dan jumlah anak ibu. Selanjutnya adalah factor proximal seperti pemberian ASI eksklusif, usia anak dan BBLR (Darteh dkk, 2014).

Dampak dari stunting bukan hanya gangguan pertumbuhan fisik anak, tapi mempengaruhi pula pertumbuhan otak balita. Lebih banyak anak ber-IQ rendah dikalangan anak stunting dibanding dengan kalangan anak yang tumbuh dengan baik. Stunting berdampak seumur hidup terhadap anak. Stunting memunculkan kekhawatiran terhadap perkembangan anak-anak karena adanya efek jangka panjang.

Prevalensi stunting di Indonesia menempati peringkat kelima terbesar di dunia. Data Riset kesehatan dasar (Riskesdas) tahun 2013 menunjukkan prevalensi stunting dalam lingkup nasional sebesar 37,2 persen, terdiri dari prevalensi pendek sebesar 18,0 persen dan sangat pendek sebesar 19,2 persen. Stunting dianggap sebagai masalah kesehatan masyarakat yang berat bila prevalensi stunting berada pada rentang 30-39 persen. Hal ini menunjukkan bahwa Indonesia sedang mengalami masalah kesehatan masyarakat yang berat dalam kasus balita stunting. berdasarkan data dari Dinas Kesehatan Aceh, prevalensi balita stunting pada 2017, Aceh berada di atas nasional yaitu $34,5 \%$, sedangkan nasional 29,6 persen. Kabupaten yang memiliki angka prevalensi stunting di atas rata-rata provinsi, yaitu Simeulue, Aceh Utara, Aceh Tengah, Bener Meriah, Aceh Tenggara, Aceh Jaya, Gayo Lues, Singkil, Aceh Timur, Pidie, Aceh Selatan, dan Kota Subulussalam. Khusus Aceh Timur angka prevalensi stunting di atas 50 persen. Ini bermakna, setengah dari total populasi balita di Aceh Timur mengalami masalah dalam proses pertumbuhan.

Berdasarkan studi pendahuluan jumlah kelompok balita stunting usia 24-59 bulan di UPTD Puskesmas Simpang Ulim lebih banyak daripada kelompok balita usia 0-23 bulan. oleh karena itu peneliti ingin meneliti factor-faktor yang mempengaruhi terjadinya stunting pada balita usia 24-59 bulan di wilayah kerja UPTD Puskesmas Simpang ulim Kabupaten Aceh timur.

\section{METODE PENELITIAN}

Penelitian ini merupakan penelitian kuantitatif yang bersifat analitik observasional dengan pendekatan kasus kontrol. Jumlah sampel dalam penelitian ini yaitu 40 responden yang terdiri dari 20 kasus dan 20 kontrol. Tehnik pengambilan sampel dalam penelitian ini adalah dengan purposive sampling. Penelitian ini dilaksanakan di wilayah kerja UPTD Puskesmas Simpang Ulim. Instrumen yang digunakan adalah formulir biodata responden, formulir 1x24 hours food recall, dan kuesioner pengetahuan ibu tentang gizi. Analisis data menggunakan uji chi square untuk mengetahui ada tidaknya hubungan yang signifikan antara variabel penelitian yang menggunakan data nominal, serta 
menggunakan tabulasi silang untuk menganalisis keeratan hubungan antara dua variabel dengan melihat nilai Odds Rasio (OR).

\section{HASIL}

Berikut penjelasan hasil yang didapat pada penelitian ini :

Tabel 1.

Tabulasi Silang Kecukupan Energi dan Protein dengan Kejadian Stunting

\begin{tabular}{|c|c|c|c|c|c|c|}
\hline \multirow{2}{*}{ Asupan Nutrisi } & \multicolumn{2}{|c|}{ Stunting } & \multicolumn{2}{|c|}{ Normal } & \multirow{2}{*}{ P-value } & \multirow{2}{*}{ OR (CI 95\%) } \\
\hline & $\mathbf{N}$ & $\%$ & $\mathbf{N}$ & $\%$ & & \\
\hline Kecukupan Energi & & & & & \multirow{3}{*}{0.003} & \multirow{4}{*}{$\begin{array}{c}9.333 \\
(2.180-39.962)\end{array}$} \\
\hline Cukup & 14 & 70 & 4 & 20 & & \\
\hline Kurang & 6 & 30 & 16 & 80 & & \\
\hline $\begin{array}{l}\text { Kecukupan Protein } \\
\text { Cukup }\end{array}$ & 14 & 70 & 5 & 475 & \multirow{2}{*}{0.006} & \\
\hline Kurang & 6 & 30 & 15 & 52.5 & & $(1.739-28.174)$ \\
\hline
\end{tabular}

Sumber: data primer 2020

Berdasarkan tabel 1 balita yang normal mendapat asupan energi yang cukup sebanyak 14 $(70) \%$ dan yang kurang sebanyak 6 balita (30\%), sedangkan pada balita stunting mayoritas mendapat asupan energy yang kurang yaitu $16(80 \%)$. Uji statistic chi square menunjukkan bahwa asupan energy yang kurang merupakan factor resiko kejadian stunting $(\mathrm{p}=0.03 ; \mathrm{OR}=9,333 ; \mathrm{Cl}=2.180$ 39.962). Sedangkan Persentase kecukupan protein yang kurang mayoritas terjadi pada kelompok stunting $(52.5 \%)$ sedangkan tingkat kecukupan protein pada kelompok balita normal mayoritas cukup (70\%). Hasil uji statistik pada penelitian ini menujukkan asupan protein yang kurang 7000 kali beresiko mengalami stunting dibanding asupan protein yang cukup $(\mathrm{p}=0.006 ; \mathrm{OR}=7000 ; \mathrm{Cl}=1.739$ 28.174).

Tabel 2.

Distribusi Silang Berat Badan Lahir dan Riwayat ASI dengan kejadian Stunting

\begin{tabular}{|c|c|c|c|c|c|c|}
\hline \multirow[b]{2}{*}{ Karakteristik balita } & \multicolumn{2}{|c|}{ Normal } & \multicolumn{2}{|c|}{ Stunting } & \multirow{2}{*}{ P-value } & \multirow{2}{*}{$\mathrm{OR}(\mathrm{Cl} 95 \%)$} \\
\hline & $\mathbf{N}$ & $\%$ & $\mathbf{N}$ & $\%$ & & \\
\hline Berat badan lahir & & & & & \multirow{3}{*}{0.635} & \multirow{3}{*}{$\begin{array}{c}1.588 \\
(0.236-10.704\end{array}$} \\
\hline $\begin{array}{l}\text { Normal } \\
\text { BBLR }\end{array}$ & $\begin{array}{c}18 \\
2\end{array}$ & $\begin{array}{l}90 \\
10\end{array}$ & $\begin{array}{l}17 \\
3\end{array}$ & $\begin{array}{l}85 \\
15\end{array}$ & & \\
\hline Riwayat ASI & & & & & & \\
\hline Eksklusif & 1 & 5 & 2 & 10 & \multirow{2}{*}{0.556} & \multirow{2}{*}{$\begin{array}{c}0.474 \\
(0.39-5.688)\end{array}$} \\
\hline Tidak Eksklusif & 19 & 95 & 18 & 90 & & \\
\hline
\end{tabular}

Sumber: data primer 2020

Berdasarkan data yang tertera pada tabel diatas menunjukkan bahwa antara kelompok bayi normal dan stunting mayoritas lahir dalam keadaan berat badan yang cukup yaitu $(90 \%)$ dan $(85 \%)$. Hasil uji statistic membuktikan bahwa Berat Badan Lahir Rendah bukan merupakan factor resiko kejadian stunting $(p=0.635 ; O R=1.588 ; C l=0.236$ 10.704). tidak adanya hubungan antara BBLR dengan stunting juga dapat disebabkan oleh efek berat lahir terbesar pada usia 6 bulan awal kemudian menurun hingga usia 2 tahun. Apabila pada 6 bulan awal, balita dapat melakukan kejar tumbuh maka terdapat peluang balita dapat tubuh dengan tinggi badan normal dan terhindar dari kejadian stunting diusia selanjutnya (Nasikhah, R. 2012).

Pada tabel dibawah terlihat bahwa pengetahuan ibu yang kurang didominasi oleh kelompok balita yang stunting (70\%) dan pengetahuan ibu yang cukup didominasi pada kelompok balita yang normal (75\%). Hasil analisis bivariat menunjukkan pengetahuan ibu merupakan factor resiko terhadap terjadinya stunting $(p=0.006$; $\mathrm{OR}=7000 ; \quad \mathrm{Cl}=1.739-28.174)$. Balita dengan pengetahuan gizi ibu yang kurang beresiko 7000 kali mengalami stunting dibandingkan dengan balita dengan pengetahuan gizi ibu yang cukup.Pengetahuan dapat memberikan pengaruh 
terhadap cara seseorang dalam memahami pengetahuan mengenai gizi, sikap dan perilakunya dalam memilih makanan dan berdampak pada status gizi seseorang. Semakin tinggi pengetahuan gizi seorang ibu maka diharapkan status gizi anak akan semakin baik. Hal ini juga dikemukakan Suhardjo, (2003), dalam jurnal (Retnaningsih) bahwa kurangnya pengetahuan dan salah satu konsepsi tentang kebutuhan pangan dan nilai pangan adalah umum disetiap negara didunia. Salah satu penyebab munculnya gangguan gizi adalah kurangnya pengetahuan tentang gizi atau kurangnya kemampuan untuk menerapkan informasi tentang gizi dalam kehidupan sehari-hari. Pengetahuan tentang gangguan kandungan zat gizi dalam berbagai bahan makanan, kegunaan makanan bagi kesehatan keluarga dapat membantu ibu memilih bahan makanan yang harganya tidak begitu mahal akan tetapi nilai gizinya tinggi.

Tabel 3.

Distribusi silang pengetahuan gizi ibu, Pendidikan Ibu, Status Pekerjaan dan Pendapatan Keluarga

\begin{tabular}{|c|c|c|c|c|c|c|}
\hline \multirow{2}{*}{ Social Ekonomi } & \multicolumn{2}{|c|}{ Normal } & \multicolumn{2}{|c|}{ Stunting } & \multirow{2}{*}{ P-value } & \multirow{2}{*}{ OR(CI 95\%) } \\
\hline & $\mathbf{N}$ & $\%$ & $\mathbf{N}$ & $\%$ & & \\
\hline Pengetahuan Gizi ibu & & & & & & \\
\hline Cukup & 15 & 75 & 6 & 30 & \multirow{2}{*}{0.006} & 7000 \\
\hline Kurang & 5 & 25 & 14 & 70 & & $(1.739-28.174$ \\
\hline Pendidikan Ibu & & & & & & \\
\hline Cukup & 16 & 80 & 3 & 15 & \multirow{2}{*}{0.000} & 22.667 \\
\hline Kurang & 4 & 20 & 17 & 85 & & $(4.374-117.468)$ \\
\hline Status Pekerjaan & & & & & & \\
\hline Bekerja & 8 & 40 & 7 & 35 & \multirow{2}{*}{0.744} & 1.238 \\
\hline Tidak bekerja & 12 & 60 & 13 & 65 & & $(0.343-4.464)$ \\
\hline Pendapatan keluarga & & & & & & \\
\hline Cukup & 17 & 85 & 6 & 30 & \multirow{2}{*}{0.001} & 13.222 \\
\hline Kurang & 3 & 15 & 14 & 70 & & $(2.790-62.670)$ \\
\hline
\end{tabular}

Sumber: data primer 2020

\section{PEMBAHASAN}

Balita dengan tingkat kecukupan energy yang kurang 9 kali beresiko mengalami stunting dibanding balita yang memperoleh asupan energy yang cukup. Asupan energy yang cukup diperlukan untuk berbagai proses metabolisme, apabila hal ini tidak terpenuhi maka efisiensi proses metabolisme tidak adekuat sehingga maturasi organ terganggu dan meningkatkan resiko berbagai penyakit. Energy diperlukan oleh tubuh untuk mendukung semua mekanisme biologis dan kimiawi di dalam tubuh. Kekurangan energy terjadi bila konsumsi energy melalui makanan kurang dari energy yang dikeluarkan, sehingga tubuh akan mengalami ketidakseimbangan energy. Akibatnya berat badan kurang dari berat badan seharusnya. Bila terjadi pada bayi dan anak-anak akan menghambat pertumbuhan dan perkembangan. Gejala yang ditimbulkan pada anak-anak adalah kurang perhatian, gelisah, lemah, kurang bersemangat dan penurunan daya tahan terhadap penyakit infeksi (Mustika, 2011 dalam Kemenkes RI, 2004).

Protein adalah salah satu makronutrien yang memiliki peranan penting dalam pembentukan biomolekul. Protein merupakan makromolekul yang menyusun lebih dari separuh bagian sel. Protein menentukan ukuran dan struktur sel, komponen utama dari enzim yang biokatalisator berbagai reaksi metabolism dalam tubuh (Kemenkes RI, 2014). Penelitian ini sejalan dengan penelitian yang dilakukan oleh Hermina dan Prihatini (2010) konsumsi protein pada balita 24-59 bulan di Indonesia masih dibawah standar angka kecukupan gizi dengan hasil rata-rata menggunakan pengukuran recall $1 \times 24$ jam sebesar $111,5 \%$. Fungsi utama protein dalam tubuh adalah untuk pertumbuhan dan pemeliharaan jaringan. Sebelum sel-sel dapat mensintesis protein baru, sel-sel tersebut harus memiliki semua asam amino esensial. Pertumbuhan atau peningkatan masa otot hanya terjadi apabila campuran asam-asam amino yang dibutuhkan terdapat dalam jumlah yang lebih banyak dibandingkan dengan yang dibutuhkan untuk pemeliharaan dan penggantian jaringan. Seseorang yang mengkonsumsi protein dengan nilai gizi rendah akan menunjukkan gejala-gejala kekurangan gizi. Hasil penelitian ini diduga penggunaan protein belum memadai dan efisien untuk proses pertumbuhan linier (Bening. S, dkk. 2016) 
Berdasarkan data yang tertera pada tabel diatas menunjukkan bahwa antara kelompok bayi normal dan stunting mayoritas lahir dalam keadaan berat badan yang cukup yaitu $(90 \%)$ dan $(85 \%)$. Hasil uji statistic membuktikan bahwa Berat Badan Lahir Rendah bukan merupakan factor resiko kejadian stunting $(p=0.635 ; O R=1.588 ; C l=0.236$ 10.704). tidak adanya hubungan antara BBLR dengan stunting juga dapat disebabkan oleh efek berat lahir terbesar pada usia 6 bulan awal kemudian menurun hingga usia 2 tahun. Apabila pada 6 bulan awal, balita dapat melakukan kejar tumbuh maka terdapat peluang balita dapat tubuh dengan tinggi badan normal dan terhindar dari kejadian stunting diusia selanjutnya (Nasikhah, R. 2012).

Penelitian ini sejalan dengan penelitian Elsa Nur Aini (2018) yang menyatakan bahwa berdasarkan hasil uji chi square menunjukkan Berat Badan Lahir Rendah (BBLR) bukan merupakan factor resiko kejadian stunting $(p=1000 ; O R=1,288$; $\mathrm{Cl}=0,318-5,219)$.

Pada variabel riwayat ASI bahwa rata-rata sampel baik dari kelompok balita normal ataupun stunting tidak mendapatkan ASI Eksklusif masingmasing $(95 \%)$ dan $(90 \%)$, sehingga hasil uji statistic pada penelitian ini menunjukkan tidak adanya hubungan antara riwayat ASI dengan kejadian stunting dengan nilai $(\mathrm{p}=0.556 ; \mathrm{OR}=0.476 ; \mathrm{Cl}=0.39$ 5.688). Hasil wawancara yang didapat mayoritas ibu tidak memberikan ASI Ekslusif karena ASI yang dihasilkan adalah sedikit sehingga harus ditambah dengan susu formula, sedangkan MP-ASI tetap diberikan setelah bayi berusia 6 bulan karena sebagian ibu responden mengetahui dampak memberikan MP-ASI terlalu dini pada bayi dapat mempengaruhi kesehatan atau daya tahan tubuh bayi. Berdasarkan teori pemberian MP-ASI sebelum usia 6 bulan dapat menyebabkan balita rawan terkena penyakit infeksi sebab saluran pencernaan bayi belum siap mencerna makanan selain ASI. Penyakit infeksi yang sering diderita oleh balita yaitu diare dan ISPA (Infeksi Saluran Pernapasan Akut). Masa windows critical yaitu masa perkembangan otak atau kecerdasan dan pertumbuhan badan yang cepat pada anak. Seorang anak akan tumbuh dengan baik jika diberikan asupan yang cukup sesuai dengan kebutuhannya meskipun anak tersebut tidak mendapatkan ASI eksklusif (Johson M and Brookstone, 2012:11).

Penelitian ini sejalan dengan penelitian Amalia Miftakhul Rochmah (2017) yang menyatakan bahwa balita dengan riwayat ASI Eksklusif lebih banyak mengalami stunting yaitu $(39,3 \%)$. Hasil statistic dengan chi-square menunjukkan bahwa didapatkan nilai $p$ 0,826 $(p>0,05)$ sehingga dapat disimpulkan bahwa tidak ada hubungan antara riwayat ASI eksklusif dengan stunting pada balita usia 24-59 bulan di wilayah kerja Puskesmas Wonosari I.

Pada variabel pendidikan ibu pada kelompok balita stunting adalah berpendidikan rendah (55\%) dan pada kelompok balita normal berpendidikan cukup (80\%). Uji statistic chi square membuktikan pendidikan ibu merupakan factor resiko terjadinya stunting ( $p=0.000 ; O R=22.667 ; \mathrm{Cl}=4.374-117.468)$. Pendidikan ibu merupakan hal dasar bagi tercapainya gizi balita yang baik. Tingkat pendidikan ibu terkait dengan kemudahan ibu dalam menerima informasi tentang gizi dan kesehatan dari luar. Ibu dengan pendidikan lebih tinggi akan lebih mudah menerima informasi dibandingkan dengan ibu yang memiliki tingkat pendidikan lebih rendah. Ibu dengan pendidikan tinggi mempunyai pengetahuan yang lebih luas tentang praktik perawatan anak serta mampu menjaga dan merawat lingkungan agar tetap bersih (Taguri, et al.,2007). Orang tua terutama ibu yang mendapatakan pendidikan yang lebih tinggi dapat melakukan perawatan anak dengan lebih baik daripada orang tua dengan pendidikan rendah. Orang tua dengan pendidikan yang lebih rendah biasanya bersal dari keluarga yang social ekonominya rendah.

Pada variabel status pekerjaan persentase ibu yang bekerja pada kelompok balita stunting $(35 \%)$ hampir sama dengan kelompok balita normal $(40 \%)$. Berdasarkan uji statistic pada penelitian ini ibu yang bekerja bukan merupakan factor resiko kejadian stunting $(\mathrm{p}=0.744 ; \mathrm{OR}=1.238 ; \mathrm{Cl}=(0.343$ 4.464). Factor status pekerjaan ibu dalam penelitian ini belum berperan sebagai penyebab utama terjadinya stunting pada balita, tetapi berperan sebagai factor yang mempengaruhi dalam pemberian makan, zat gizi serta pola pengasuhan anak. Tidak adanya hubungan antara pekerjaan ibu dengan kejadian stunting dapat disebabkan ibu yang tidak bekerja belum tentu memiliki pola pengasuhan anak yang lebih baik dibanding ibu yang bekerja karena berdasarkan hasil wawancara kebanyakan ibu yang tidak bekerja mempunyai beban lebih besar dalam mengurus pekerjaan rumah tangga sehingga terkadang tidak memiliki waktu yang cukup dalam mempersiapkan berbagai jenis olahan makanan yang bervariasi untuk kebutuhan gizi anak. Pola asuh anak yang kurang baik juga tidak selalu disebabkan oleh status pekerjaan seorang ibu melainkan dapat disebabkan oleh factor lain seperti kurangnya pengetahuan ibu mengenai gizi. Penelitian ini sejalan dengan Elsa Nur Aini (2018) yaitu persentase ibu yang bekerja pada kelompok stunting $(44,7 \%)$ hampir sama dengan kelompok 
normal (31,6\%). Uji statistic chi Square menunjukkan ibu yang bekerja bukan merupakan factor resiko kejadian stunting $(\mathrm{p}=0,892 ; \mathrm{OR}=1,754 ; \mathrm{Cl}=0,688$ 4,474).

Pada variabel pendapatan keluarga menunjukkan bahwa pendapatan perkapita keluarga yang kurang persentasenya lebih kelompok balita stunting (70\%) dibandingkan dengan kelompok balita normal (15\%). Uji statistic menunjukkan pendapatan perkapita keluarga yang kurang merupakan factor resiko kejadian stunting $(p=0.001 ; \quad O R=13.222$; $\mathrm{Cl}=2.790-62.670$ ). Balita dengan pendapatan perkapita keluarga yang kurang beresiko 13.222 mengalami stunting dibandingkan balita dengan pendapatan perkapita keluarga yang cukup. Status ekonomi yang rendah dianggap memiliki dampak yang signifikan terhadap kemungkinan anak menjadi kurus dan pendek. Keluarga dengan status ekonomi baik akan dapat memperoleh pelayanan umum yang lebih baik seperti pendidikan, pelayanan kesehatan, daya beli yang tinggi terhadap aneka jenis makanan yang bergizi sedangkan pendapatan keluarga yang rendah menyebabkan berkurangnya daya beli keluarga terhadap makanan zat gizi yang baik sehingga menyebabkan kekurangan gizi baik, zat gizi makro maupaun mikro. Sebagian besar anak balita yang mengalami gangguan pertumbuhan memiliki status ekonomi yang rendah. Semakin tinggi pendapatan seseorang akan mempengaruhi tingkat konsumsi seseorang, dan semakin tinggi tingkat pengetahuan gizi seseorang maka semakin tinggi pila variasi makanan yang dikonsumsi (Suhardjo, 2003 dalam jurnal Retnaningsih 2011)

\section{KESIMPULAN}

Asupan energi dan protein yang kurang, pengetahuan ibu yang kurang, pendidikan ibu yang rendah serta pendapatan keluarga yang rendah merupakan fakor resiko terjadinya stunting pada balita usia 24-59 bulan di wilayah kerja UPTD Puskesmas Simpang Ulim

\section{SARAN}

Bagi pihak Puskesmas dan lintas sektoral yang terkait diharapkan dapat meningkatkan pengetahuan ibu tentang kebutuhan nutrisi pada balita melalui kegiatan penyuluhan gizi yang meliputi edukasi mengenai angka kecukupan gizi pada balita sesuai umur, cara mengolah makanan yang benar, serta memberikan bantuan finansial bagi keluarga yang tidak mampu. Bagi ibu balita diharapkan dapat aktif mengikuti kegiatan posyandu supaya lebih sering terpapar dengan informasi pemenuhan nutrisi pada balita.

\section{DAFTAR PUSTAKA}

Anisa, Paramitha. (2012). Faktor-Faktor Yang Berhubungan Dengan Kejadian Stunting Pada Balita Usia 25-60 Bulan Di Kelurahan Kalibaru Depok Tahun 2012 (Skripsi). Depok: FKM UI.

Aini, Elsa Nur. 2018. Faktor yang mempengaruhi Stunting pada balita usia 24-59 bulan di Puskesmas Cepu Kabupaten Blora (Jurnal kesmas). Bagian Gizi Kesehatan Masyarakat. UNDIP Semarang.

Miftakhul Rochmah, Amalia. (2017). Faktor-Faktor Yang Berhubungan Dengan Stunting Pada Balita Usia 24-59 Bulan Diwilayah Kerja Puskesmas Wonosari I (Naskah Publikasi). Prodi DIV Bidan Pendidik. Fakultas IImu Kesehatan Universitas 'AISYIYAH Yogyakarta.

Astari, L. D. A. Nasoetion, dan Dwiriani C. M. (2005).Hubungan Karakteristik Keluarga, Pola Pengasuhan, Dan Kejadian Stunting Anak Usia 6-12 Bulan. Media gizi keluarga. Diakses pada 2 Agustus 2019 dari www.repository.ipb.ac.id

BAPPENAS. (2011). Rencana Aksi Nasional Pangan dan Gizi 20112015.http://www.4shared.com/get/ 145gBOZ/Ren can a_Aksi_Nasion al_Pan gan . Diakses 10 November 2019.

Bening, S. A. Margawati dan A. Rosidi. 2016. Asupan Gizi Makro dan Mikro Sebagai Faktor Resiko Stunting Anak Usia 2-5 Tahun di Semarang. Medica Hospitalia. 4(1): 45-50

Damanik, MR., Ekayanti, I.,Hariyadi, D. (2012). Analisis Pengaruh Pendidikan Ibu terhadap Status Gizi Balita di Propinsi Kalimantan Barat. Jurnal Gizi dan Pangan Juli 2005 (2): 69-77.

Darteh E.K., Acquah E. dan Kyereme A.K. 2014. Correlates of Stunting among children in Ghana terdapat dalam jurnal BMC Public Health 2014, 14:504

Depkes RI. (2008). Profil Kesehatan Indonesia 2007. Departemen Kesehatan RI.Jakarta.

Diana, Fivi. (2006). Hubungan Pola Asuh dengan status gizi anak batita di kecamatan kuranji kelurahan pasar ambacang kota padang 2004. Jurnal Kesehatan Masyarakat. Vol. 1 (1).

Hermina, Prihatini, S. (2011). Gambaran Keragaman Makanan dan Sumbangannya Terhadap Konsumsi Energi Protein Pada Anak Balita Pendek (Stunting) di Indonesia. Puslitbang Gizi dan Makanan, Badan Litbangkes 
Kemenkes RI. Jurnal Badan Litbangkes, Vol.39, No 2, hal 62-73.

Hidayat, A.A. (2009). Pengantar IImu Kesehatan Anak untuk Pendidikan Kebidanan. Jakarta : Salemba Medika.

Hien, NN. dan Kam, S. (2008). Nutritional Status and the Characteristics Related to Malnutrition in Children Under Five Years og Age in Nghean, Vietna. J Prev Med Public Health. 41 (4): 232240.

Kemenkes RI.(2017). Data dan Informasi Profil Kesehatan Indonesia 2016. Pusat Data dalggrhrtn Informasi:Jakarta.

Kusharisupeni. (2007).Gizi dan Kesehatan Masyarakat. Jakarta: Raja grafindo Persada.

Nasikhah, R dan Margawati, A. 2012. Factor resiko kejadian stunting pada balita usia 24-36 bulan di Kecamatan Semarang Timur. Journal of Nutrition College, 1(1).
Neldawati.(2006). Hubungan Pola Pemberian Makanan pada Anak dan Karakteristik Lain dengan Status Gizi di Laboratorium Gizi Masyarakat. Puslitbang Gizi dan Makanan (P3GM) (Analisis Data Sekunder Data Balita Gizi Buruk Tahun 2005). Depok: FKM UI.

Notoatmodjo, S. (2003). Pendidikan Dan Perilaku Kesehatan. Rineka Cipta. Jakarta.

Oktarina, Z.,Sudiarti, T.(2013). Faktor Risiko Stunting Pada Balita 24-59 bulan di Sumatera.Jurnal Gizi dan Pangan,Vol 8, No.3.

Retnaningsih, CH. 2011. Penilaian Status Gizi Berdasarkan Kecukupan Energi Kalori dan Protein pada Balita (Usia 3-5 Tahun) di Desa Gogik Kecamatan Ungaran Barat Kabupaten Semarang. Seri Kajian IImiah. Volume 14, No:2 